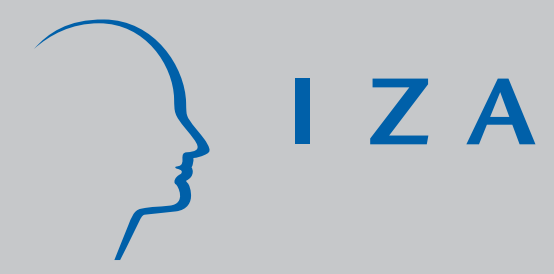

IZA DP No. 3890

Migration and Globalization: Challenges and Perspectives for the Research Infrastructure

Martin Kahanec

Klaus F. Zimmermann

December 2008 


\title{
Migration and Globalization: Challenges and Perspectives for the Research Infrastructure
}

\author{
Martin Kahanec \\ IZA \\ Klaus F. Zimmermann \\ IZA, DIW Berlin, Bonn University \\ and Free University Berlin \\ Discussion Paper No. 3890 \\ December 2008 \\ IZA \\ P.O. Box 7240 \\ 53072 Bonn \\ Germany \\ Phone: +49-228-3894-0 \\ Fax: +49-228-3894-180 \\ E-mail: iza@iza.org
}

\begin{abstract}
Any opinions expressed here are those of the author(s) and not those of IZA. Research published in this series may include views on policy, but the institute itself takes no institutional policy positions.

The Institute for the Study of Labor (IZA) in Bonn is a local and virtual international research center and a place of communication between science, politics and business. IZA is an independent nonprofit organization supported by Deutsche Post World Net. The center is associated with the University of Bonn and offers a stimulating research environment through its international network, workshops and conferences, data service, project support, research visits and doctoral program. IZA engages in (i) original and internationally competitive research in all fields of labor economics, (ii) development of policy concepts, and (iii) dissemination of research results and concepts to the interested public.
\end{abstract}

IZA Discussion Papers often represent preliminary work and are circulated to encourage discussion. Citation of such a paper should account for its provisional character. A revised version may be available directly from the author. 


\begin{abstract}
Migration and Globalization: Challenges and Perspectives for the Research Infrastructure*

International migration of people is a momentous and complex phenomenon. Research on its causes and consequences, requires sufficient data. While some datasets are available, the nature of migration complicates their scientific use. Virtually no existing dataset captures international migration trajectories. To alleviate these difficulties, we suggest: (i) the international coordination of data collection methodologies and standardization of immigrant identifiers; (ii) a longitudinal approach to data collection; (iii) the inclusion of adequate information about relevant characteristics of migrants, including retrospective information, in surveys; (iv) minimal anonymization; (v) immigrant boosters in existing surveys; (vi) the use of modern technologies and facilitation of data service centers; and (vii) making data access a priority of data collection.
\end{abstract}

JEL Classification: J15, J18, J61, J68

Keywords: migration, immigrants, data collection, data access, data infrastructure

Corresponding author:

Klaus F. Zimmermann

IZA

P.O. Box 7240

53072 Bonn

Germany

E-mail: Zimmermann@iza.org

\footnotetext{
* This Paper was commissioned by the Rat für Sozial- und Wirtschaftsdaten (RatSWD) within the project "Developing the Research Infrastructure for the Social Sciences (including the Behavioral Sciences) in Germany and Beyond: Progress since 2001, Current State, and Future Demands". The views expressed are the authors' alone and do not necessarily correspond to those of RatSWD. We thank Uwe G. Rehfeld and the participants to the Second Workshop of RatSWD for helpful comments.
} 


\section{Introduction}

The international migration of people lies at the core of the ongoing process of globalization. People migrate to improve their economic prospects, ensure a more secure living environment, re-unite with their family members, or avoid persecution in their country of origin. These among other reasons motivated the 3\% of the world's population who found themselves on an international migration trajectory in 2005. Since a large proportion of migrants head towards developed countries, the share of international migrants in these countries reached as much as 9.5\% in $2005 .{ }^{1}$ These people experience not only important economic and social consequences of their move, but also psychological ones. Migration may involve a new job with higher pay, losing old and establishing new social ties, as well as psychological costs of missing the homeland.

Migration, however, does not only affect the fate of those who are directly involved. Various effects emerge at the interface of migrant and native populations. Immigrants may bring with them new cultures or preferences, compete for certain jobs and create others, or claim publicly financed social security benefits. More broadly, migrants contribute to a more efficient allocation of resources and often become a driving force of knowledge transfer and technological advancement. All these effects have repercussions for the native population, who may react to migrant inflows not only with regards to their current action, but also to long-term investment plans such as those concerning education. Finally, natives may view immigrants positively or negatively and form their attitudes accordingly.

Migration is a dynamic phenomenon involving many twists and turns. Driven by a multitude of possible reasons, migrants may move temporarily or permanently, transnationally and nationally, individually or in groups, return to their countries of origin or migrate to another country, or move between two or more countries in a circular way. The complex underlying processes driving migration and its effects have attracted a significant and growing attention of scientists. Chiswick (1978) and Borjas (1985) pioneered scientific work on immigrant adjustment in host societies. This literature highlights the significance of experience in the host country and stresses the importance of cohort effects, country of origin, religion, education, as well as a number of demographic characteristics such as age and gender. From a different

\footnotetext{
${ }^{1}$ See United Nations, Department of Economic and Social Affairs, World Migrant Stock: The 2005 Revision Population Database.
} 
perspective, the study of the migration decision has been inspired and advanced by Harris and Todaro (1970), Becker (1964), Mincer (1978), and Borjas (1985). Immigrant self-selection discussed by Borjas (1987) and Chiswick (1999) implies the need for specific techniques (Heckman, 1979) to consistently evaluate causal mechanisms behind immigrant adjustment.

The impact of immigration on the host labour market has been modelled by Chiswick, Chiswick and Karras (1992) and Chiswick (1998). A large body of empirical literature, summarized by Kahanec and Zimmermann (2008), provides mixed evidence on the sign and determinants of these effects on wages and employment. ${ }^{2}$ More recently, the roles of intermarriage (Meng and Gregory, 2005), citizenship (Bratsberg, Ragan and Nasir, 2002), social networks (Munshi, 2003), and attitudes (Bauer, Lofstrom and Zimmermann, 2000; Kahanec and Tosun, 2009) concerning immigrant adjustment have received significant attention. The concept of ethnic identity has been extended by Constant and Zimmermann (2008), who elaborate on how attachment to the country of origin and the host country affect immigrant adjustment.

Although measuring the effects of migration is a nontrivial job, migration undoubtedly affects the well being of the whole society and as such, has become an important and sensitive policy issue. It is especially the questions of the labor market consequences of migration, immigrant adjustment in host societies, and welfare competition that have received significant policy attention.

Understanding the causes and effects of international migration flows requires a sound and in-depth analysis. The need for such analysis is most conspicuous in the study of causal relationships, as these are difficult to establish empirically and their misrepresentation compromises both scientific and policy analyses. In fact, it may lead to incorrect policy recommendations, which may lead to unpredictable consequences or even effects contrary to those intended. Since such analysis is impossible without high quality data, such data are indispensable for policy analysts as well as scientists.

\footnotetext{
${ }^{2}$ The evidence on migration effects in source countries is mainly related to remittances (e.g. Barham and Boucher 1998), and wage and employment effects (Brücker 2007).
} 


\section{Which data are available and used?}

Despite the general scarcity of migration data, scientists and analysts have been able to use some existing survey or administrative datasets as well as small-scale dedicated survey data to study migration issues. While these datasets have facilitated valuable research, missing variables, excessive anonymization, and flaws in data collection design often compromise scientists' efforts to broaden and deepen our knowledge of migration causes and effects. In this section we focus on some large-scale datasets collected at the European level, as they, in contrast to small-scale surveys, have an intrinsic potential to provide the necessary transnational, longitudinal and systematic data collection framework.

There are four extensive datasets that cover in some dimension European migration trajectories: European Community Household Panel (ECHP), EU Statistics on Income and Living Conditions (EU-SILC), EU Labour Force Survey (EU-LFS), and the OECD/SOPEMI dataset. Each of these datasets contains information about demography, labour force participation, employment, unemployment, selfemployment, and educational attainment of immigrants. In addition, the European Social Survey (ESS) covers people's attitudes towards immigrants as well as their voting preferences, thus addressing migration indirectly.

Table 1 depicts the character of these datasets, highlighting some of their strengths and weaknesses. We can identify at least three major gaps in the available data. ${ }^{3}$ Firstly, these datasets provide none or only a very limited account of migration trajectories. Transnational migration trajectories may involve simple or repetitive moves between two or more countries with temporary spells of various lengths as well as permanent moves. It is almost impossible to track such trajectories - with all their spells, stops, and circularities - within Europe, and between Europe and third countries. In particular, no or little information is available on migrants' experience prior to their arrival to the country of current residence or their intentions on further moves. Secondly, the data typically permit determining immigrant status based on an individual's citizenship and country of origin, neglecting the large groups of people with an immigrant background who are native citizens, or those with dual citizenships. Finally, anonymization often renders any valuable analysis impossible,

\footnotetext{
${ }^{3}$ See also the discussion in Bauer and Zimmermann (1998).
} 
for example when immigrants from very different origins (e.g. Zimbabwe and Japan) are grouped into one category (e.g. non-EU).

\section{Data access issues and needs}

Inadequate access to existing datasets is one of the most limiting factors for scientific and policy analysis. Due to restrictive data access policies, a lack of interest on the side of the officials responsible, misinterpreted data protection rules, or just the lack of adequate data access infrastructure, the use of datasets for scientific and policy purposes is, in general, severely limited. Since migration is, by definition, a transnational and dynamic phenomenon (i.e. involving one-way as well as repeat, sequential and circular movement between more countries), its proper analysis requires a combination of information from more countries and across more periods. ${ }^{4}$ Therefore, restrictions on data access and a lack of coordination of access rules are particularly detrimental to the analysis of migration issues. Below we list some of the most pressing issues that obstruct availability of data for migration analysis and determine the needs concerning collection of adequate data on migration.

One of the main problems is that identifying and defining migrants in the existing datasets is not a trivial matter. The migration background, foreign origin (foreign born), citizenship, or ethnicity can be used to determine whether or not someone is an immigrant. Unfortunately, only a subset of this information, if any, is available in existing datasets. Only rarely can one identify first, second, and further generations of immigrants, citizens and non-citizens, and distinguish immigrants of different origin and ethnicity.

It is even more seldom possible to obtain information that characterizes migration trajectories. Perhaps with the exception of length of stay in the host country, pre-migration experience, track of all migration moves, or migration trajectories of family members (spouses) are hardly available. While the lack of data describing migration trajectories of those who make more frequent, possibly circular, moves is a general problem, it is particularly problematic in the case of high-skill migrants, as these are the most fluid and mobile segment of the migrant population.

\footnotetext{
${ }^{4}$ Bauer, Pereira, Vogler and Zimmermann (2002) have merged Portuguese data and German data on Portuguese migrants to be able to compare migrants in the sending and a receiving country. See Crul and Vermeulen (2006) for another project in this spirit.
} 
Other relevant and often missing information include language, religion, and attachment to the host society and the country of origin.

A further related problem is that the effects of out-migration are hard to capture, as we typically do not observe people who leave or their characteristics (they do not deregister and are in a different country when data are collected). In fact, this deficiency creates problems for the analysis of the entire population as well, since it compromises the representativeness of datasets. For example, according to the Weekly Report of the German Institute for Economic Research (Wochenbericht des DIW) (2008, p. 382), doubts arose in Germany as to whether the official census statistics still represented the actual reality of the German population. As the German national census data has only been based on registers since 1987 - which depend on proper registering and deregistering of people - those who leave the country and do not deregister are erroneously counted. An example of the magnitude of the measurement error which can result from failing to track out-migration of those who have not deregistered was revealed in a clean up of the data from the German Central Register of Foreigners (Ausländerzentralregister) in 2004, which showed that the official census statistics had overstated the number of foreigners in Germany by about 600,000 .

Another difficulty is that most datasets are representative of the total population and contain a limited number of observations. While this does not need to be a problem in other contexts, in the context of migration it often implies insufficient samples of the immigrant population. In addition, many datasets are cross-sectional and thus do not capture the dynamic nature of migration. In particular, the snapshot picture that such datasets provide can but capture the most recent move and cannot distinguish some important effects, such as those of host country experience and immigrant cohort on immigrant adjustment.

Finally, knowledge of migration intentions and reasons, and their relationship to actual migration decisions is indispensable for predicting future migration flows as well as for understanding migrants' outcomes in the host societies. Precise estimates of the directions and characteristics of such flows are crucial for designing effective and efficient immigration policies, for instance in the context of EU enlargement. The intentions to stay, namely, whether migrants perceive their situation as temporary or they come to settle in the host country permanently, bears important consequences for their labor market behavior and thus the effects they exert on the host economy. 
Similarly, migrants who come for economic reasons and those that come as refugees or asylum seekers have very different labor market opportunities as well as intentions in the host country.

These issues concerning availability and access to adequate migration data determine the main needs concerning collection of such data. In particular, collected data should properly identify migrants and people with immigrant background, and contain sufficient samples of migrants. They should cover (transnational) migration trajectories and, in particular, capture pre-migration experience and out-migration, and measure intentions and reasons for migration.

\section{Future developments and challenges}

The enlargement of the European Union and the concurrent expansion of the European Economic Area as well as the persistent economic and social hardship and insecurity in large parts of the world will continue to fuel substantial international flows of people. High-quality data are and will remain a key ingredient to understanding the causes and effects of these migration flows. Given the traditional prominence of quantitative techniques in economics and the strengthening emphasis on such techniques in other social sciences, especially sociology, we can project increasing demand for such data among scientists in the future. This demand will be further strengthened by the increasing need for well-founded policy analysis at European and national levels. Another contributing factor may be the business sector, which may seek to exploit the potential benefits from precise information about their current and potential customers.

The provision of high-quality migration data is in general insufficient, albeit somewhat improving over the last decade or two. This improvement has been enabled by the emergence of advanced information and data management technologies that can facilitate a wide access to existing datasets. This development concerns especially some international institutions that have started to provide access to some of their datasets (European Union, World Bank, ILO, UN) and private and non-governmental organizations (IZA). While some improvements have been made at the national level, governmental institutions still lag behind in data access provision. More recently, some remarkable developments have taken place involving a partnership between public and non-governmental or private institutions aiming at a wider dissemination of valuable data collected by public institutions. For instance, the IZA Data Service 
Center (IDSC) offers on-site computing via ultra thin access, and remote computing by means of a remote computing solution ( $\mathrm{JoSuA}$ ) facilitating the use of scientific use data of the German Federal Statistical Office. ${ }^{5}$

These positive developments should not hide the difficult reality of migration research and analysis concerning data availability. Besides the various difficulties that migration researchers face regarding identification of migrants in existing datasets as well as a lack of relevant information about them, virtually no existing dataset has the necessary transnational and longitudinal perspective to capture complete migration trajectories. This defines the key challenge in this respect: to track migrants and their migration experience as they move internationally. The associated practical challenge is to coordinate data collection methodologies across Europe and, even more difficult, between Europe and third countries.

\section{Conclusions and recommendations}

This essay summarizes some of the key problems and challenges related to the availability of data for the study of migration issues. Given the long-standing as well as more recent developments in migration research, it is apparent that access to data of good quality harmonized across time and countries is one of the key bottlenecks hindering advances in our understanding of the causes and effects of migration. To alleviate this problem, there are a number of policy tools that may help.

First, coordination of data collection methodologies and standardization of immigrant identifiers across the EU would facilitate international comparability. It is necessary to harmonize data collection methods so that migration trajectories in Europe-wide datasets can be observed. In particular, unique individual identifiers need to be tractable across European countries. An open method of coordination, transparent indicators, benchmarking, and an efficient exchange of best practices seem to be the way to go in this regard. This also has to do with merging datasets transnationally and across time, including proper harmonization and linking of data,

\footnotetext{
${ }^{5}$ The IZA Data Service Center, one of the data service centers facilitated by the so called KVI Commission, offers an integrated service which consists of a metadata portal and a remote computing solution. The IDSC's metadata service comprises a detailed, in depth, searchable and standardized information and documentation service on a growing number of datasets currently in the areas of employment and wages, education and training, and demographics and migration. The IDSC remote computing solution, known as JoSuA, facilitates usage of restricted datasets bridging the otherwise wide gap between legal constraints and scientific freedom without violating the former or constraining the latter. For further details see Schneider and Wolf (2008).
} 
records, and topics. In particular, given the advancement in data management and storage technologies, this objective concerns not only prospective but also retrospective harmonization and merging of datasets as well, involving digitalization of old datasets whenever necessary.

Second, whenever possible, a longitudinal approach should be adopted to facilitate separation of spurious effects driven by unobserved cross-sectional variation from true causal relationships as well as to capture the dynamic nature of migration. In this regard, one should also consider extending selected existing cross-sectional datasets by surveying the covered individuals in one or more additional waves.

Third, adequate information about relevant characteristics of migrants experience in the host society (years since migration), country of origin, citizenship, ethnicity, language, religion, attachment to the host society and the country of origin, and migration intentions and reasons - is requisite. For example, of key importance is to distinguish temporary and permanent migrants as well as economic migrants from those that come as refugees or asylum seekers, or as tied movers. Retrospective questions in survey questionnaires are necessary to track migrants' pre-migration experience (i.e experience prior to the last observed move).

Fourth, anonymization should be limited to the smallest possible degree. As an option, alternative anonymization procedures could be applied to the same dataset, allowing two or more versions being accessible to the researcher, each facilitating research on different research questions.

Fifth, immigrant boosters in existing surveys, with a well defined control group, would facilitate sufficient immigrant sample sizes. Sixth, online data service centers, data registers and metadatabases can provide an invaluable service to the research community. In fact, the Internet itself is becoming a rich source of data, and a tool to collect new data, which still needs to be properly exploited.

Sixth, the use of modern data information technologies should be promoted to facilitate collection, management and storage of as well as and, importantly, access to good quality data. Within this objective, creation of data service centers facilitating prudent access to such data is desirable.

Finally, facilitation of data access to researchers should be embraced as one of the objectives of data collection. Adequate efforts by all the involved actors are necessary not only to facilitate knowledge about migration as such, but also, to the 
extent that suitable policies are adopted, to improve the welfare of substantial numbers of people directly or indirectly affected by migration.

\section{References}

Barham, B. and S. Boucher. 1998. "Migration, Remittances and Inequality: Estimating the Net Effects of Migration on Income Distribution”, Journal of Development Economics 55(2): 307-331.

Bauer, T., M. Lofstrom and K. F. Zimmermann. 2000. "Immigration Policy, Assimilation of Immigrants, and Natives' Sentiments towards Immigrants: Evidence from 12 OECD Countries”, Swedish Economic Policy Review 7:11-53.

Bauer, T. and K. F. Zimmermann. 1998. "Causes of International Migration: A Survey”, in C. Gorter, P. Nijkamp and J. Poot (Eds.), Crossing Borders: Regional and Urban Perspectives on International Migration, Aldershot: Ashgate Publishing Ltd, 95-127.

Bauer, T., P. T. Pereira, M. Vogler and K. F. Zimmermann. 2002. "Portuguese Migrants in the German Labor Market: Performance and Self-Selection”, International Migration Review 36(2): 467-491.

Becker, G. S. 1964. Human Capital, New York, National Bureau of Economic Research.

Borjas, G. J. 1985. “Assimilation, Changes in Cohort Quality, and the Earnings of Immigrants”, Journal of Labour Economics 3(4): 463-489.

Borjas, G. J. 1987. "Self-Selection and the Earnings of Immigrants", American Economic Review 77(4):531-553.

Bratsberg, B., J. F. Ragan and Z. M. Nasir. 2002. "The Effect of Naturalization on Wage Growth: A Panel Study of Young Male Immigrants”, Journal of Labor Economics 20(3): 568-597.

Brücker, H. 2007. “Migration after the EU’s Eastern Enlargement: Who Wins, Who Loses?”, Paper presented at Second IZA Migration Workshop: EU Enlargement and the Labor Markets, Bonn 7-8 September 2007.

Chiswick, B. R. 1978. "The Effect of Americanization on the Earnings of Foreignborn Men”, Journal of Political Economy 86(5): 897-921.

Chiswick, B. R. 1998. “The Economic Consequences of Immigration: Application to the United States and Japan”, in M. Weiner and T. Hanami (Eds.), Temporary 
Workers or Future Citizens? Japanese and U.S. Migration Policies, New York: New York University Press, 177-208.

Chiswick, B. R. 1999. “Are Immigrants Favorably Self-Selected?”, American Economic Review 89(2): 181-185.

Chiswick, C. U., B. R. Chiswick and G. Karras. 1992. “The Impact of Immigrants on the Macroeconomy”, Carnegie-Rochester Conference Series on Public Policy 37: 279-316.

Constant, A. and K. F. Zimmermann 2008. "Measuring Ethnic Identity and Its Impact on Economic Behavior", Journal of the European Economic Association, 6(2-3): 424-433

Crul, M. and H. Vermeulen. 2006. "Immigration, education and the Turkish second generation in five European nations: a comparative study”, in C. A Parsons and T. M. Smeeding (Eds.), Immigration and the Transformation of Europe, Cambridge: Cambridge University Press, 236-250.

Harris, J. R. and M. P. Todaro. 1970. "Migration, Unemployment and Development: A Two-Sector Analysis”, The American Economic Review 60(1): 126-142.

Heckman, J. J. 1979. “Sample Selection Bias as a Specification Error”, Econometrica 47(1): 153-161.

Kahanec, M. and M. Tosun. 2009. "Political Economy of Immigration in Germany: Attitudes and Citizenship Aspirations”, International Migration Review, 43(2), forthcoming.

Kahanec, M. and K. F. Zimmermann. 2008. "International Migration, Ethnicity and Economic Inequality”, IZA Discussion Paper No. 3450.

Meng, X. and R. G. Gregory. 2005. "Intermarriage and economic assimilation of immigrants”, Journal of Labor Economics 23(1):135-175.

Mincer, J. 1978. “Family Migration Decisions”, Journal of Political Economy, 86(5): 749-773.

Munshi, K. 2003. "Networks in the Modern Economy: Mexican Migrants in the U. S. Labor Market”, The Quarterly Journal of Economics, 118(2):549-599.

Schneider, H. and C. Wolf. 2008. "Die Datenservicezentren als Teil der informationellen Infrastruktur”, in G. Rolf, M. Zwick and G. G. Wagner (Eds.): Fortschritte der informationellen Infrastruktur in Deutschland, Baden-Baden: Nomos.

Weekly Report of the German Institute for Economic Research (Wochenbericht des DIW). 2008. Nr. 27-28/2008, DIW Berlin. 
Table 1. Datasets

\begin{tabular}{|c|c|c|c|c|c|}
\hline Dataset & Type & Years & Countries & $\begin{array}{c}\text { Measures of immigrant } \\
\text { status }\end{array}$ & $\begin{array}{l}\text { Weakness } \\
\text { (selected) }\end{array}$ \\
\hline ECHP & $\begin{array}{l}\text { Longi- } \\
\text { tudinal }\end{array}$ & $\begin{array}{l}1994- \\
2001\end{array}$ & EU 15 & $\begin{array}{l}\text { Year of arrival } \\
\text { (region/country), } \\
\text { Country of birth, First } \\
\text { and second citizenship, } \\
\text { Mother tongue }\end{array}$ & $\begin{array}{l}\text { No information on } \\
\text { the immigrant's } \\
\text { experience prior to } \\
\text { his/her arrival to the } \\
\text { country of present } \\
\text { residence. }\end{array}$ \\
\hline $\begin{array}{l}\text { EU- } \\
\text { SILC }\end{array}$ & $\begin{array}{l}\text { Longi- } \\
\text { tudinal }\end{array}$ & $\begin{array}{l}2004- \\
2006\end{array}$ & $\begin{array}{l}\text { Until } 2004 \\
\text { EU15 } \\
\text { Since } 2006 \\
\text { EU25 }\end{array}$ & $\begin{array}{l}\text { Country of birth, } \\
\text { Citizenship (first) }\end{array}$ & $\begin{array}{l}\text { Anonymization } \\
\text { leading to a mixing of } \\
\text { immigrants from very } \\
\text { different origins. }\end{array}$ \\
\hline EU-LFS & Survey & $\begin{array}{l}1983- \\
2006\end{array}$ & $\begin{array}{l}\text { BE, CZ, DK, } \\
\text { DE, EE, GR, } \\
\text { ES, FR, IE, } \\
\text { IT, CY, LV, } \\
\text { LT, LU, HU, } \\
\text { MT, NL, AT, } \\
\text { PL, PT, SI, } \\
\text { SK, FI, SE, } \\
\text { UK, BG, RO } \\
\text { (+HR, TR, IS, } \\
\text { NO, CH) }\end{array}$ & $\begin{array}{l}\text { Nationality } \\
\text { (citizenship), Years of } \\
\text { residence, Country of } \\
\text { birth (anonymized), } \\
\text { Country of residence } \\
\text { one year before the } \\
\text { survey }\end{array}$ & $\begin{array}{l}\text { Anonymization } \\
\text { leading to a mixing of } \\
\text { immigrants from very } \\
\text { different origins. }\end{array}$ \\
\hline $\begin{array}{l}\text { OECD/ } \\
\text { SOPEMI }\end{array}$ & $\begin{array}{l}\text { Macro- } \\
\text { data }\end{array}$ & $\begin{array}{l}1983- \\
2008\end{array}$ & OECD & $\begin{array}{l}\text { Stocks of foreign } \\
\text { nationality and foreign } \\
\text { born populations, } \\
\text { Country of birth, Flows } \\
\text { of foreign-born } \\
\text { workers }\end{array}$ & $\begin{array}{l}\text { While the dataset } \\
\text { provides aggregate } \\
\text { data, no information } \\
\text { about the individual } \\
\text { characteristics of } \\
\text { migrants is available }\end{array}$ \\
\hline ESS & $\begin{array}{l}\text { Cross- } \\
\text { sectional }\end{array}$ & $\begin{array}{l}2002 \\
2004 \\
2006\end{array}$ & EU25 & $\begin{array}{l}\text { Voting preferences, } \\
\text { Attitudes toward } \\
\text { immigrants and ethnic } \\
\text { minorities }\end{array}$ & $\begin{array}{l}\text { The cross sectional } \\
\text { nature of the dataset } \\
\text { does not capture the } \\
\text { dynamic nature of } \\
\text { migration. }\end{array}$ \\
\hline
\end{tabular}

